\title{
Alat Pengukur Saturasi Oksigen Dalam Darah Menggunakan Metode Photoplethysmograph Reflectance
}

\author{
Candra Rizki Nugroho ${ }^{1}$, Elvan Yuniarti ${ }^{1 \dagger}$, Ambran Hartono ${ }^{1}$ \\ ${ }^{1}$ Program Studi Fisika, Fakultas Sains dan Teknologi, Universitas Islam Negeri Syarif Hidayatullah Jakarta \\ $\dagger$ elvan.yuniarti@uinjkt.ac.id
}

\begin{abstract}
ABSTRAK
Kekurangan oksigen pada tubuh dapat menyebabkan tubuh merasa mudah lelah, letih dan mengantuk, ini dikarenakan oksigen berperan sebagai salah satu sumber energi bagi tubuh selain nutrisi. Salah satu alat yang dapat mendiagnosa tubuh seseorang kekurangan oksigen adalah oximeter. Penelitian ini bertujuan untuk merancang bangun hardware serta software alat ukur saturasi oksigen menggunakan metode PPG reflectance menggunakan arduino Nano dan sensor MAX30100, menentukan karakteristik, membandingkan hasil pengukuran dengan alat pengukur saturasi oksigen yang menggunakan metode transmittance. Hasilnya telah berhasil merancang dan membangun alat pengukur saturasi oksigen $\left(\mathrm{SpO}_{2}\right)$ dengan menggunakan sensor MAX30100 dan arduino Nano yang dapat dimonitoring pada HP menggunakan bluetooth HC-05 dengan jangkauan kurang dari $140 \mathrm{~m}$ pada ruang terbuka dengan tanpa halangan, waktu respon 5 detik, memiliki ketelitian pengukuran rata-rata di atas $96 \%$ serta keakuratan sebesar 95,2\%.
\end{abstract}

Kata kunci : Arduino Nano, MAX30100, Oksigen, Oximeter, $\mathrm{SpO}_{2}$

\section{ABSTRACT.}

Lack of oxygen in human body can cause the body to easily feel tired, exhausted and sleepy. It happens because oxygen acts as a source of energy for human body besides nutrition. There is an device that can diagnose the lack of oxygen in human body called oximeter. This study aims to design and build both hardware and software to measure the oxygen saturation with the PPG reflectance by using arduino and max30100 sensor, determine the characteristic, and to compare the measurement results with oxygen saturation gauges device that uses transmitance method then analyze it. The results of this study are the oxygen saturation gauges device has been designed and built by using the MAX30100 sensor and arduino Nano that can be monitored on a cellphone using Bluetooth HC-05 with a range of less than $140 \mathrm{~m}$ in open space without obstacle, 5 seconds of response time, has an average measurement accuracy above $96 \%$ and an accuracy of $95.2 \%$.

Keywords: Arduino Nano, MAX30100, Oxygen, Oxymeter, SpO2

DOI : 10.15408/fiziya.v3i2.17721 


\section{PENDAHULUAN}

Oximeter adalah alat yang digunakan untuk memonitor keadaan jumlah oksigen dalam darah tanpa harus melalui tes darah (non-invasive). Alat ini memanfaatkan sifat gelombang cahaya infrared dan LED merah yang dapat menembus jaringan dan dipantulkan kembali oleh tulang atau jaringan lain dalam tubuh serta sensor cahaya sebagai penerima gelombang cahaya. Pada penelitian ini, bertujuan merancangbangun alat oximeter, mengkarakteristiknya dan membandingkan dengan alat yang dibangun dengan metode reflektan dan metode transmitan buatan pabrik .

\section{Darah}

Darah merupakan salah satu jaringan tubuh dalam sistem pembuluh darah yang sebenarnya tertutup. Darah dibagi dalam dua fungsi yaitu fungsi respirasi dan fungsi gizi. Fungsi respirasi yaitu sebagai pengangkut oksigen $\left(\mathrm{O}_{2}\right)$ dan karbon dioksida $\left(\mathrm{CO}_{2}\right)$. Dalam satu sel darah terdiri dari hemoglobin, eritrosit, hematrosit, retikulosit, laju endap darah, trombosit, dan lekosit [1][2].

\section{Photosplethysmograph (PPG)}

Photoplethysmography atau PPG merupakan metode yang digunakan untuk mengukur perubahan volume darah pada pembuluh darah yang dekat dengan lapisan kulit manusia berbasis optic secara non invasif. PPG memiliki dua metode pengukuran secara transmitan dan reflektans[3]. Prinsip kerja PPG hanya memerlukan beberapa komponen sumber cahaya yang panjang gelombangnya dapat disesuaikan dengan kebutuhan dan sebuah photodetektor untuk merubah perubahan radiasi gelombang cahaya menjadi sama dengan perubahan volume darah \{Formatting Citation\}. Metode PPG adalah metode yang berbasis optik, pengukurannya meliputi jumlah foton yang dikirimkan pada suatu titik terhadap satuan waktu tertentu disebut dengan intensitas (I). Karena cahaya bergerak dengan kecepatan yang konstan yaitu, $c=3 \times 10^{8} \mathrm{~m} / \mathrm{s}$ dan nilai absorbsi berbanding lurus dengan panjang lintasan yang harus dilalui cahaya. Ketika panjang lintasan mempunyai satuan $\mathrm{cm}$, dan konsentrasi zat penyerap mempunyai satuan Molaritas, maka nilai konstanta proposional tersebut disebut Absorbtivitas Molar. Maka koefisien atenuasi molar $(\varepsilon)$ zat mempunyai satuan $\mathrm{M}^{-1} \mathrm{~cm}^{-1}$ sehingga menjadi,

Dimana:

$$
A=\varepsilon \times l \times c
$$

A $=$ Nilai absorbsi

$\varepsilon=$ koefisien atenuasi molar

$1=$ panjang lintasan

$\mathrm{c}=$ konsentrasi zat

Pengukuran ini mempunyai dua metode yaitu transmittance dan reflectance.

Metode transmittance dilakukan yaitu dengan cara meletakkan jari diantara LED dan fotodiode. Pada metode ini, sumber cahaya akan melewati/menembus pembuluh darah untuk mengukur perubahan volume darah sebelum cahaya diterima oleh fotodiode. Kelemahan pada metode ini yaitu terbatasnya area yang dapat diukur, hanya pada bagian jari tangan, jari kaki, hidung, pipi, lidah dan daun telinga saja yang dapat diukur[8][9].

Sedangkan pada metode reflectance dilakukan dengan cara meletakkan jari di atas sumber cahaya dan fotodiode dengan posisi sejajar. Sumber cahaya akan melalui pembuluh darah dan dipantulkan dari jaringan, tulang dan pembuluh darah menuju fotodiode. Metode ini dapat diaplikasikan pada bagian kulit tubuh mana saja yang terdapat pembuluh darah[10] [11].

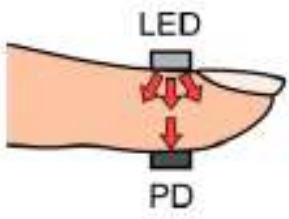

(a)

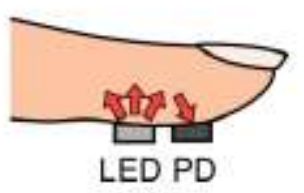

(b)

Gambar 1 Metode PPG (a) Transmittance (b) Reflectance

\section{Sensor MAX30100}

Sensor MAX30100 adalah pulse sensor yang terintegrasi dan digunakan untuk memonitoring $\mathrm{SpO}_{2}$ dan denyut jantung secara non-invasive [12]. Sensor MAX30100 terdiri dari dua Light Emiting Dioda (LED) yaitu LED merah dan infrared serta sebuah photodetektor dengan pemerosesan sinyal 
analog noise rendah [13]. Darah yang mengandung oksigen akan menyerap panjang gelombang yang dihasilkan oleh infrared yaitu sebesar $900 \mathrm{~nm}$ sedangkan darah yang tidak mengandung oksigen akan menyerap panjang gelombang yang dihasilkan oleh LED merah yaitu sebesar $650 \mathrm{~nm}$ [14].

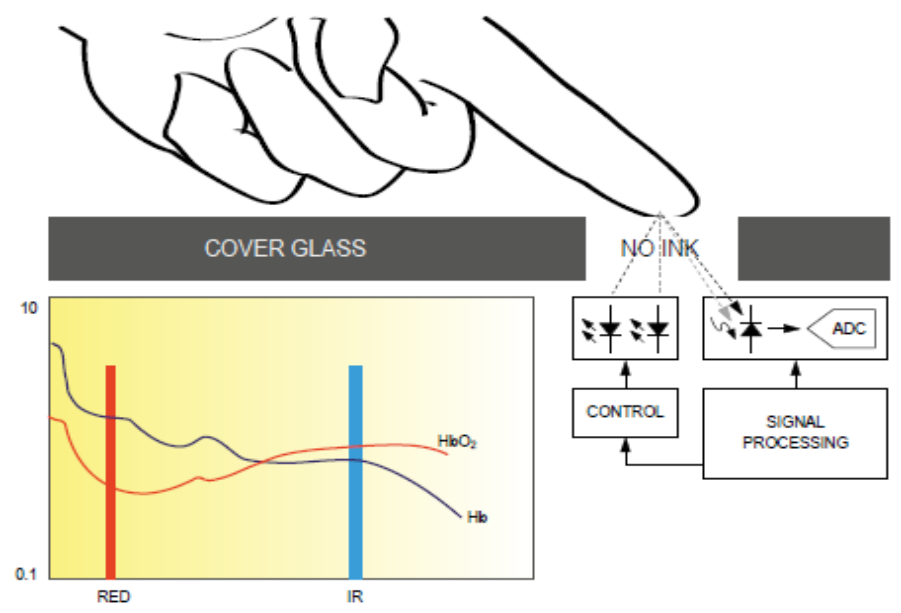

Gambar 2 Prinsip Kerja Sensor MAX30100

Dari gambar di atas dapat dilihat ilustrasi prinsip kerja dari sensor MAX30100. Cahaya dari LED merah hanya menyerap hemoglobin saja sedangkan cahaya dari infrared akan menyerap hemoglobin yang mengandung oksigen. Perbedaan penyerapan ini menjadi acuan untuk menentukan saturasi oksigen.

\section{METODOLOGI PENELITIAN}

\section{Waktu dan Tempat}

Penelitian ini dilakukan selama 2 bulan terhitung dari 15 Juni 2019 - 31 September 2019, bertempat di gedung Pusat Laboratorium Terpadu (PLT) Universitas Islam Negeri Syarif Hidayatullah Jakarta.

\section{Peralatan Penelitian}

Peralatan pada penelitian ini menggunakan dua jenis perangkat, yaitu perangkat keras (hardware) dan perangkat lunak (software). Komponen dan alat yang digunakan pada perangkat keras diantaranya Sensor Max30100, Arduino Nano, USB Serial Cable A/B, Resistor 4.7k $\Omega$, kabel malefemale, Project Board, Bluetooth HC-05, Liquid Crystal Display (LCD) 16x2, Laptop, Handphone Android, Pulse Oximeter dan papan Arklik. Sedangkan perangkat lunak (software) yang digunakan yakni IDE Arduino dan RemoteXY. 


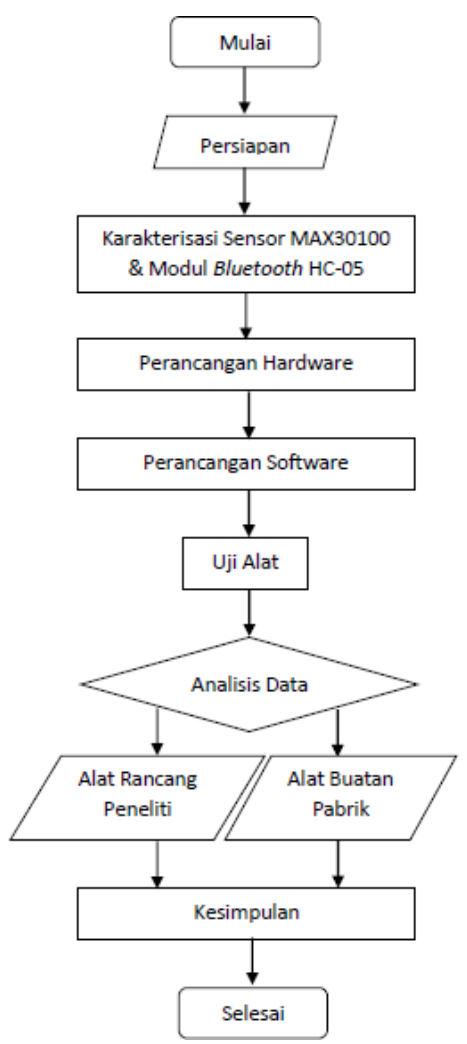

Pada perancangan hardware alat pengukur saturasi oksigen dalam darah, sensor MAX30100 di letakkan pada sebuah ruang kecil berwarna gelap sehingga saat pengukuran berlangsung didapatkan data yang maksimal dan mengurangi noise. Desain perancangan hardware alat pengukur kadar oksigen dalam darah dapat dilihat pada gambar berikut.

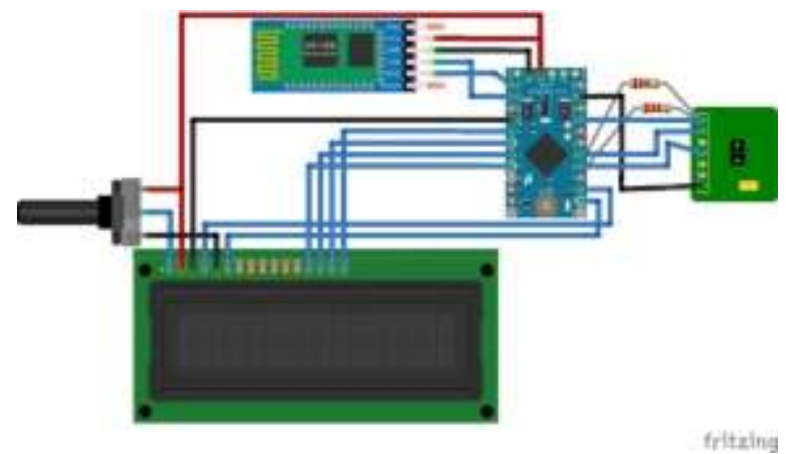

Gambar 3. Rancangan Hardware

Pada Gambar di atas, terdapat dua resistor yang digunakan sebaga1 pull-up untuk sensor MAX30100. Selain itu, peneliti menggunakan arduino Nano Shield untuk mempermudah dan memperbanyak jumlah pin.

Sedangkan untuk software yang digunakan untuk perancangan alat ukur kadar oksigen dalam darah adalah Arduino IDE. Arduino sebagai penerima hasil pembacaan dari sensor MAX30100, maka dari itu Arduino harus diisikan dengan program berupa source code. Selanjutnya Arduino akan memproses hasil pembacaan dan mengeluarkan hasil pembacaan pada LCD dan interface Android menggunakan software RemoteXY dengan modul Bluetooth HC-05. 


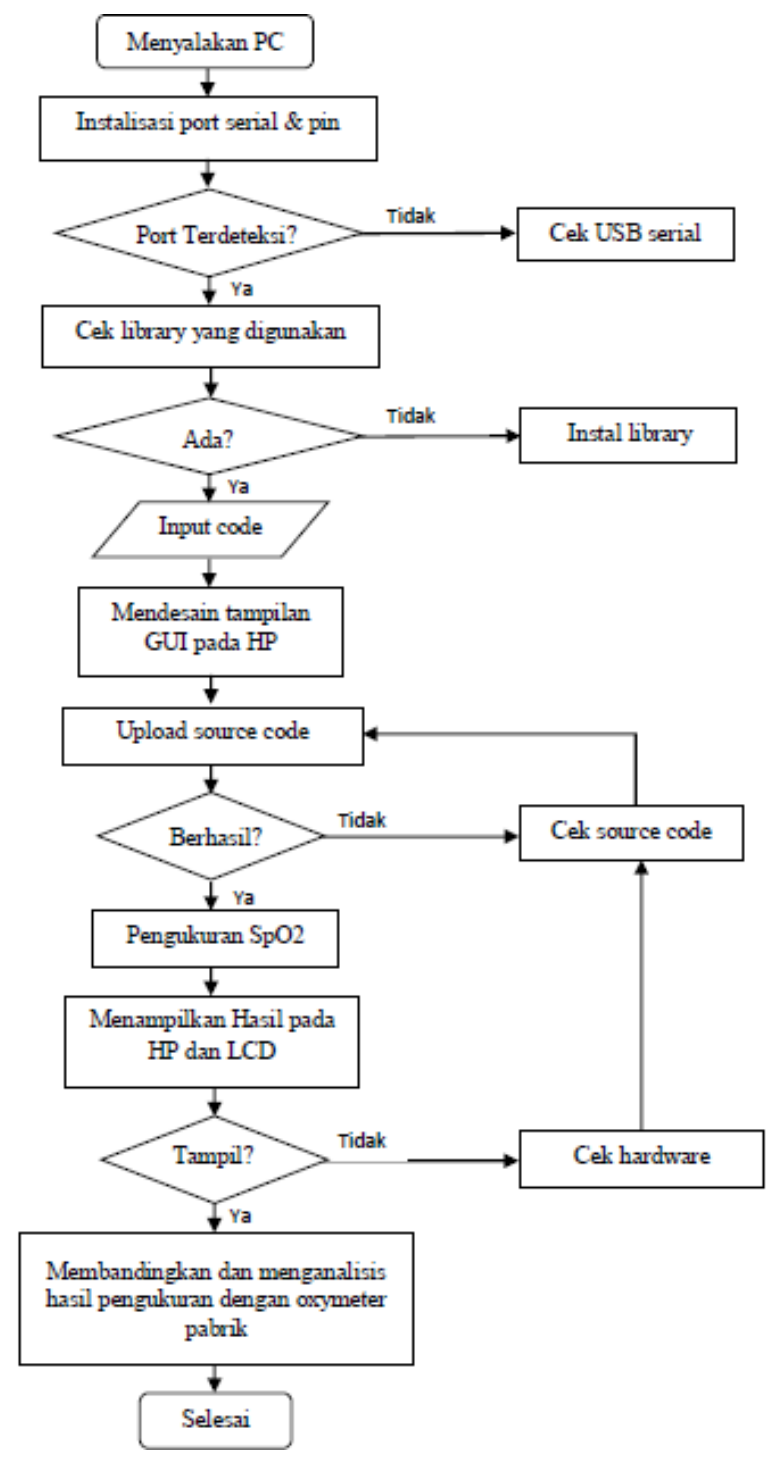

Gambar 6. Flowchart Perancangan Software

\section{Pengambilan Data}

Metode yang digunakan untuk pengambilan data adalah dengan cara melakukan percobaan pada beberapa relawan laki-laki dan perempuan dengan jenjang umur 7-12 tahun dan umur 13-25 tahun. Data diambil dengan cara menaruh ujung jari telunjuk pada sensor dan dilakukan selama 10 detik lamanya. Pengukuran dilakukan dengan dua metode yaitu metode PPG Reflectance dan metode PPG Transmittance.

\section{Pengolahan Data}

Data yang diperoleh akan diolah menggunakan metode regresi linier dan standar deviasi. Metode perhitungan regresi linier digunakan agar dapat memperediksi nilai error yang terjadi jika dilakukan pengukuran selanjutnya. Berikut merupakan rumus regresi linier dan standar deviasi:

$$
\begin{aligned}
& s^{2}=\frac{\sum_{i=1}^{k} x y^{2}-\frac{\left(\sum_{i=1}^{k} x y\right)^{2}}{n}}{n-1} \\
& s=\sqrt{s^{2}}
\end{aligned}
$$

Rumus nilai keakuratan dari alat ukur yang dirancang dengan oximeter yang sudah ada adalah:

$$
X=\left|\frac{X_{S p O 2}}{X_{O x i}}\right| x 100 \%
$$

$\mathrm{X}=$ Persentase perbandingan dari kedua alat ukur

$\mathrm{X}_{\mathrm{SpO} 2}=$ Rata-rata dari alat saturasi oksigen yang dibuat

$\mathrm{X}_{\mathrm{Oxi}} \quad=$ Rata-rata dari alat oximeter 
Dalam perancangan alat ukur saturasi oksigen dalam darah, peneliti melakukan dua tahap perancangan yaitu hardware dan software. Berikut merupakan hasil perancangan hardware dan software:

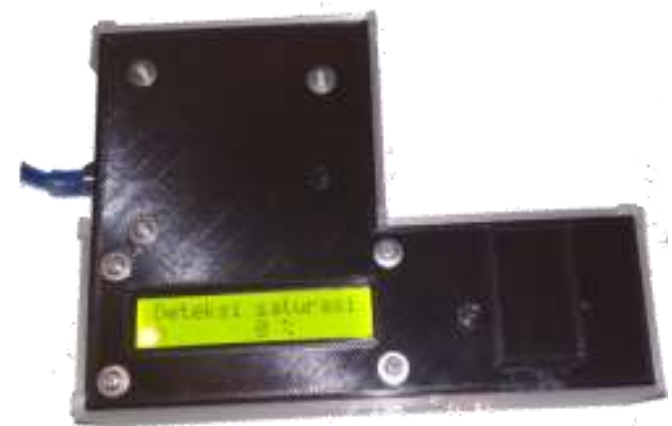

(a)

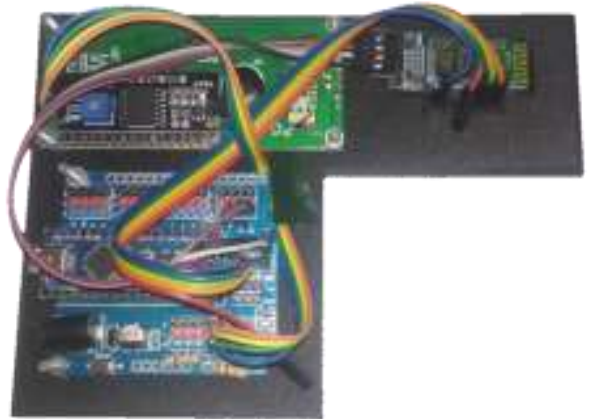

(b)

Gambar 4. Tampilan Awal Alat Pengukur Saturasi Oksigen dengan (a) Tampak Luar dan (b) Tampak Dalam

Hasil perancangan hardware pada penelitian ini meliputi perancangan alat ukur saturasi oksigen dalam darah dengan keluaran yang didapatkan berupa nilai detak jantung per menit (BPM) dan kadar saturasi oksigen dengan satuan persen (\%). Nilai tersebut didapat setelah berhasil melakukan perancangan software dengan cara memasukan source code yang sesuai pada Arduino IDE. Setelah menginput source code pada Arduino IDE, langkah selanjutnya yaitu membuat tampilan Guide User Interface (GUI) pada HP menggunakan aplikasi RemoteXY. Berikut merupakan hasil desain GUI pada HP yang dibuat:

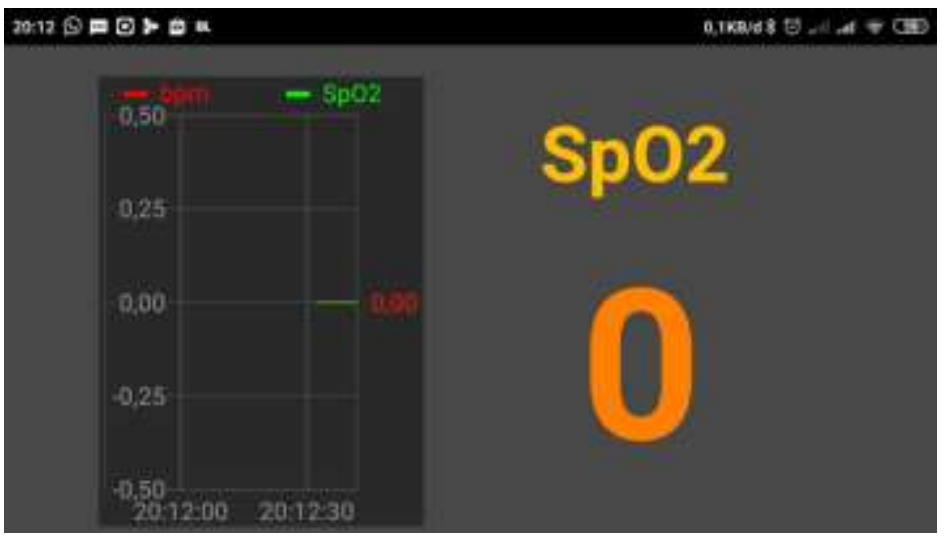

Gambar 5 Hasil GUI Pada HP

\section{Hasil dan Pengolahan Data}

Pengujian dilakukan pada beberapa orang dengan rentang umur yang berbeda, yaitu umur 22 tahun, 23 tahun, 7 tahun dan 8 tahun. Pengujian ini bertujuan untuk membandingkan alat pengukur saturasi oksigen buatan yang menggunakan metode PPG reflectance dengan alat oximeter yang menggunakan metode PPG transmittance. Berikut merupakan hasil pengolahan data yang dilakukan menggunakan alat yang dibuat dengan alat yang sudah ada (transmittance).

Tabel 1. Pengolahan Data $\mathrm{SpO}_{2}$ Alat yang dibuat dengan Alat Oximeter Pabrik

\begin{tabular}{|l|c|c|c|c|c|c|}
\hline \multirow{2}{*}{ Jenis Kelamin/Umur } & \multicolumn{3}{|c|}{ Reflectance } & \multicolumn{3}{c|}{ Transmittance } \\
\cline { 2 - 7 } & $\mathrm{SpO}_{2}$ & Standar Deviasi & Ketelitian & $\mathrm{SpO}_{2}$ & Standar Deviasi & Ketelitian \\
\hline Laki-laki/22 Tahun & 96 & 0 & $100 \%$ & 96,6 & 0,699 & $99,3 \%$ \\
\hline Perempuan/23 Tahun & 96,8 & 0,422 & $99,58 \%$ & 91,2 & 0,919 & $99,08 \%$ \\
\hline Perempuan/8 Tahun & 95,9 & 0,316 & $99,68 \%$ & 98,5 & 0,527 & $99,47 \%$ \\
\hline Perempuan/7 Tahun & 95 & 0,943 & $99,06 \%$ & 79 & 3,162 & $96,84 \%$ \\
\hline Keakuratan & \multicolumn{7}{|c|}{$95,2 \%$} \\
\hline
\end{tabular}

Tabel 2. Pengolahan Data BPM Alat yang dibuat dengan Alat Oximeter Pabrik 


\begin{tabular}{|l|c|c|c|c|c|c|}
\hline $\begin{array}{c}\text { Jenis } \\
\text { Kelamin/Umur }\end{array}$ & BPM & $\begin{array}{c}\text { Standar } \\
\text { Deviasi }\end{array}$ & Ketelitian & BPM & $\begin{array}{c}\text { Standar } \\
\text { Deviasi }\end{array}$ & Ketelitian \\
\hline Laki-laki/22 Tahun & 53,6 & 1,075 & $98,92 \%$ & 57,9 & 0,568 & $99,43 \%$ \\
\hline Perempuan/23 Tahun & 71,3 & 3,529 & $96,47 \%$ & 72,7 & 0,949 & $99,05 \%$ \\
\hline Perempuan/8 Tahun & 93,8 & 12,426 & $87,57 \%$ & 121,4 & 0,699 & $99,3 \%$ \\
\hline Perempuan/7 Tahun & 89,7 & 14,469 & $85,53 \%$ & 76,8 & 9,886 & $90,11 \%$ \\
\hline Keakuratan & \multicolumn{7}{|c|}{$93,8 \%$} \\
\hline
\end{tabular}

Dari tabel 1 dapat diketahui bahwa nilai $\mathrm{SpO}_{2}$ cenderung lebih stabil dibandingkan nilai BPM. Normalnya, nilai saturasi oksigen besarnya di atas 90\%. Ketidakstabilan nilai BPM dikarenakan jantung terus memompa darah dalam tubuh sehingga membuat darah terus bergerak. Pergerakan darah dalam tubuh bersifat acak dan cepat sehingga menyebabkan gelombang infrared menjadi tidak stabil. Maka dari itu, pada pengukuran menggunakan metode PPG Transmittance terdapat noise saat pengukuran relawan anak perempuan (7 tahun) yang menyebabkan nilai kecil namun masih sesuai dengan nilai normalnya [15]. Noise ini terjadi karena pada jari anak perempuan (7 tahun) terlalu kecil sehingga adanya gelombang cahaya dari LED merah tidak dapat menembus jaringan pada jari sepenuhnya sehingga membuat gelombang cahaya LED merah tidak tertangkap oleh photodiode.

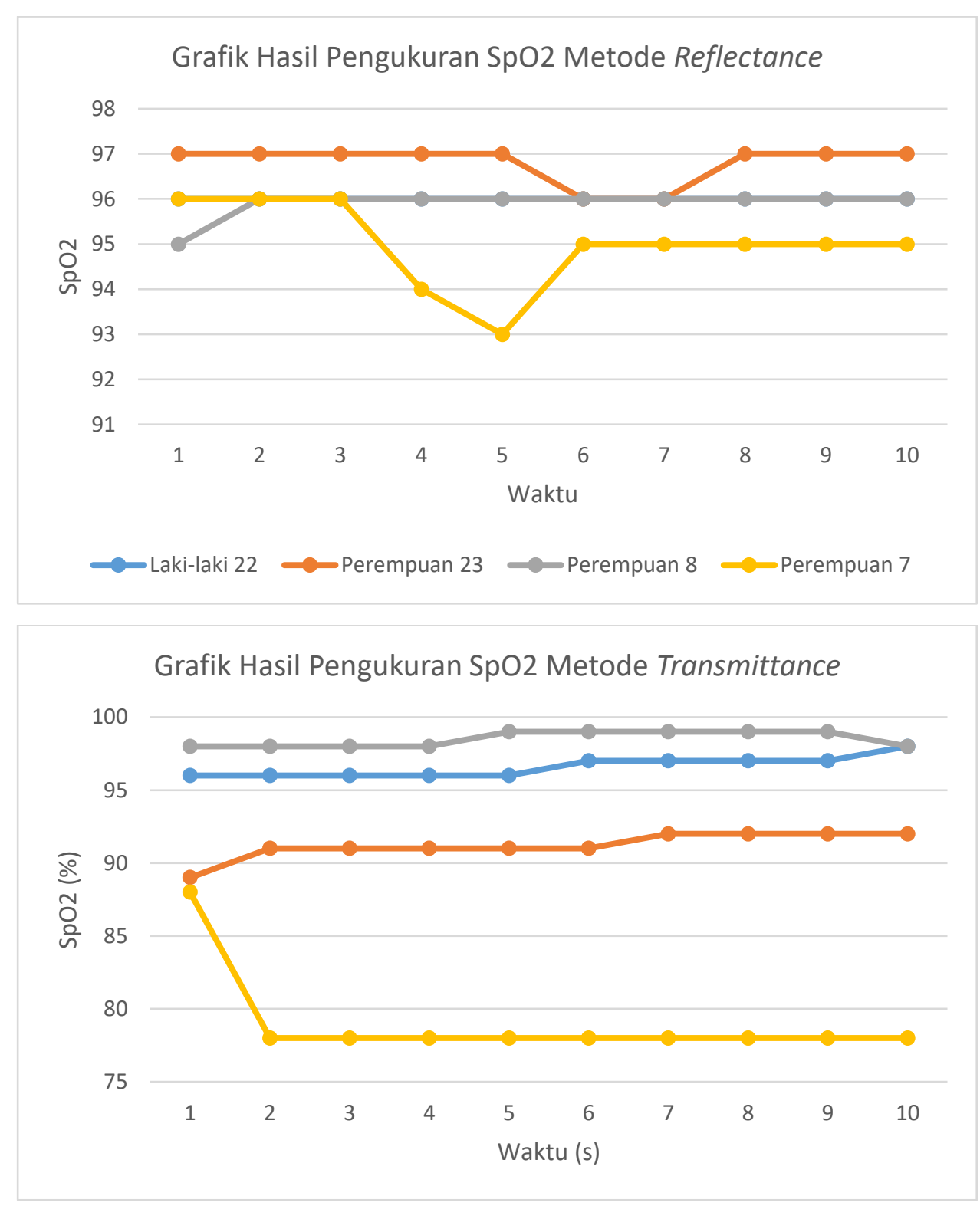

Gambar 6. Grafik Perbandingan $\mathrm{SpO}_{2}$

Dari gambar Dapat dilihat hasil pengukuran saturasi oksigen menggunakan metode PPG Reflectance lebih stabil dibandingnkan dengan metode PPG Transimittance. Respon waktu rata-rata atau perubahan pada pengukuran $\mathrm{SpO}_{2}$ metode reflectance terjadi pada detik ke-5. Meskipun berbeda tetapi masih menunjukan hasil yang sama. 


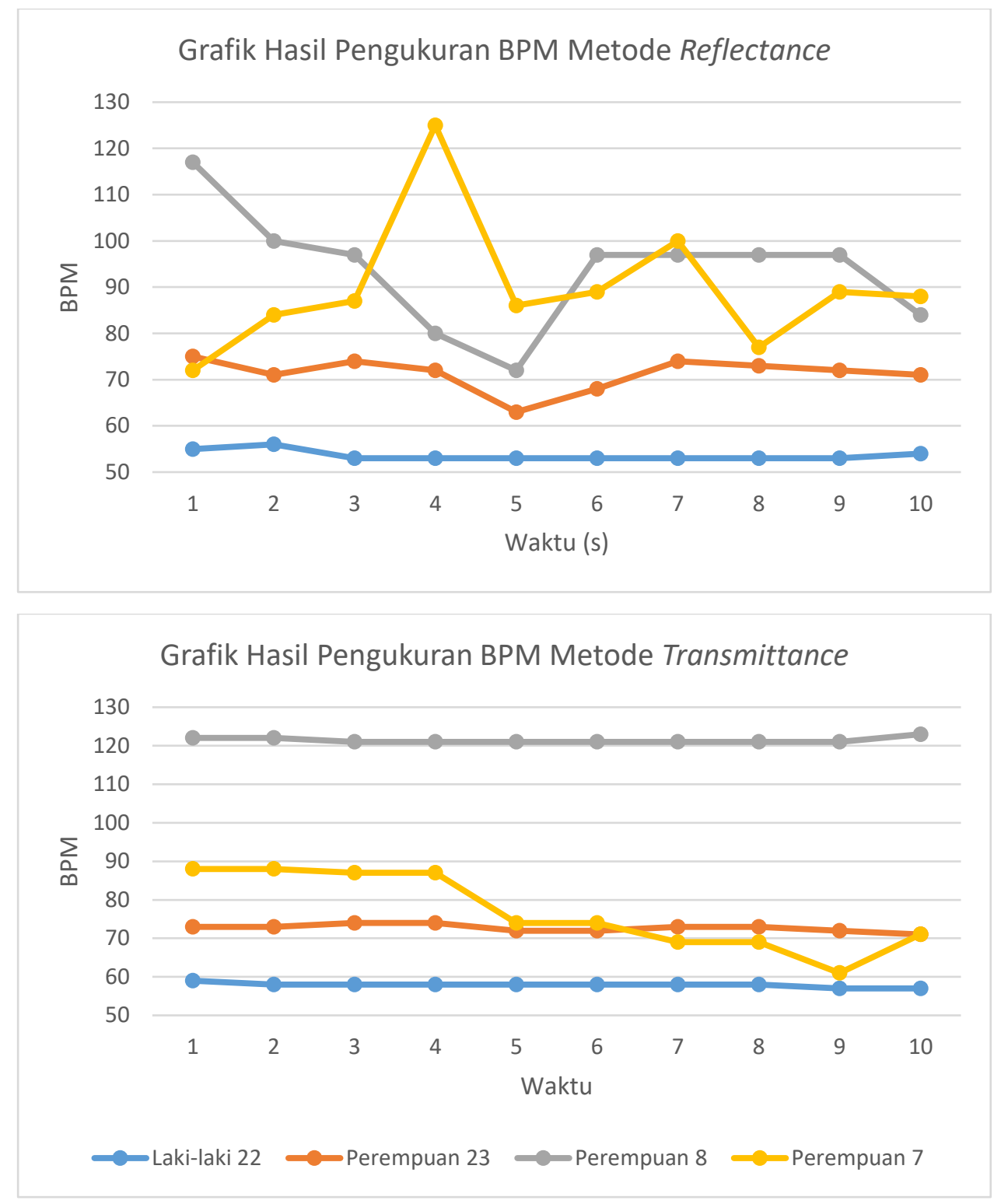

Gambar 7. Grafik Perbandingan BPM

Dari gambar 4. dapat dilihat hasil grafik menunjukan perbedaan yang tidak terlalu signifikan pada pengukuran BPM. Grafik dari metode transmittance cenderung lebih stabil dibandingkan dengan metode reflectance, karena pada metode transmittance memiliki tingkat akurasi yang lebih tinggi dalam mengukur BPM. Ketidakstabilan ini dikarenakan saat mengukur BPM sensor hanya menggunakan LED merah sebagai pengukurnya, sedangkan sensor tersebut sudah diseting untuk mengukur LED dan infrared. Walaupun nilainya sedikit berbeda, namun menunjukan informasi yang sama.

\section{KESIMPULAN}

Berdasarkan alat saturasi oksigen yang telah dirancang dan bangun, maka dapat ditarik kerimpulan sebagai berikut:

1. Telah berhasil merancang dan membangun alat pengukur saturasi oksigen $\left(\mathrm{SpO}_{2}\right)$ portable dengan menggunakan metode Photopletysmograph (PPG) Reflectance dengan waktu respon sebesar 5 detik, ketelitian pengukuran rata-rata di atas $96 \%$ berdasarkan alat oximeter yang sudah ada dan keakuratan sebesar 95,2\% serta dapat dimonitoring menggunakan bluetooth dengan jangkauan maksimal sejauh 140 meter.

2. Hasil karakterisasi sensor MAX30100 mempunyai intensitas cahaya yang dipancarkan dengan range sebesar 115 Lux sampai 178 Lux.

3. Hasil pengukuran saturasi oksigen $\left(\mathrm{SpO}_{2}\right)$ pada metode reflectance lebih stabil dibandingkan dengan metode transmittance, sedangkan hasil pengukuran BPM pada metode transmittance jauh lebih stabil dibandingkan dengan metode reflectance.

\section{REFERENSI}

[1] L. A. H. W. Endah, 'Integrasi Biokimia dalam Modul Kedokteran.' Jakarta: Lembaga Penelelitian UIN Syarif Hidayatullah Jakarta, 2010.

[2] R. C. Ningsih, D. "Rancang bangun Pulse Oximetry Berbasis Perconal Computer Sebagai 
Deteksi Kejenuhan Oksigen dalam Darah." Program, S. Jaringan, T. Digital, T. Elektro, and P. N. Malang vol. 17, no. November, pp. 1461, 201-158.

[3] F. UGHI, "Simulasi Kadar Saturasi Oksigen untuk Evaluasi Pulse Oximete", ELKOMIKA J. Tek. Energi Elektr. Tek. Telekomun. Tek. Elektron., vol. 6, no. 1, p. 110, 2018, doi: 10.26760/elkomika.v6i1.110.

[4] et al. E. Simonson, S. Koff, A. Keys, "Contour of the toe pulse, reactive hyperemia, and pulse transmission velocity: group and repeat variability, effect of age, exercise, and disease," Am. Heart J., vol. 50, no. 2, pp. 260-279, 1955.

[5] E. Simonson, "Photoelectric plethysmography; methods, normal standards, and clinical application," Geriatrics, vol. 11, no. 10, p. 425, 1956.

[6] A. V. J. Challoner, "Photoelectric plethysmography for estimating cutaneous blood flow," Non-Invasive Physiol. Meas., vol. 1, pp. 125-151, 1979. 67, 2015.

[7] L.K.Hema 1 , R. Mohana Priya 2 , R. Indumathi 3," "DESIGN AND DEVELOPMENT OF IOT BASED PULSE OXIMETER L.K.Hema 1, R. Mohana Priya 2 , R. Indumathi 3," vol. 119, no. 16, pp. 1863-1868, 2018.

[8] M. C. Carreiras, "A Pulse Oximeter Thesis to obtain the Master of Science degree in Biomedical Engineering Examination Comittee,” no. July, 2013. [9] R. R, S. P, and S. P, "Design and Development of Miniaturized Pulse Oximeter for Continuous Spo2 and HR Monitoring with Wireless Technology," Int. J. New Technol. Res., vol. 1, no. 1, p. 263706, 2015.

[10] H. Lee, H. Ko, and J. Lee, “2016.10.004Reflectance p Practical issues and limitations," ICT Express, vol. 2, no. 4, pp. 195-198, 2016, doi: 10.101ulse oximetry: 6/j.icte...

[11] T. Tamura, Y. Maeda, M. Sekine, and M. Yoshida, "Wearable Photoplethysmographic Sensors—Past and Present," pp. 282-302, 2014.

[12] R. Patel, R. Dubey, S. Mishra, and S. K. Bharti, "Tele-Monitoring Device for Cardiorespiration Activity," pp. 282-287, 2018.

[13] D. Bagus, S. Budi, R. Maulana, and H. Fitriyah, "Sistem Deteksi Gejala Hipoksia Berdasarkan Saturasi Oksigen dan Detak Jantung Menggunakan Metode Fuzzy Berbasis Arduino,” vol. 3, no. 2, pp. 19251933, 2019.

[14] C. P. Oximeter and H. Sensor, "Pulse Oximeter and Heart-Rate Sensor IC for Wearable Health Beneits and Features MAX30100 Pulse Oximeter and Heart-Rate Sensor IC for Wearable Health Absolute Maximum Ratings Supply Current in Shutdown," pp. 1-30.

[15] T. M. Kadarina and R. Priambodo, "Monitoring heart rate and SpO2 using Thingsboard IoT platform for mother and child preventive healthcare," IOP Conf. Ser. Mater. Sci. Eng., vol. 453, no. 1, 2018, doi: 10.1088/1757-899X/453/1/012028. 